\title{
THE EVALUATION OF THE ORGANIC LOAD OF THE WASTE OFFSET DEVELOPER WITH EXTRACTION METHODS
}

\author{
Savka Adamović (D), Ivan Pinćjer (D), Bojan Banjanin (D), Stefan Đurđević (iD, Nada Miketić \\ University of Novi Sad, Faculty of Technical Sciences, \\ Department of Graphic Engineering and Design, Novi Sad, Serbia
}

\begin{abstract}
The validation of the extraction method is significant for the characterization of the offset effluent and the selection of an adequate effluent treatment for its safe disposal in a printing environment. For the aforementioned reasons, the qualitative characterization of the organic load profile of the waste offset developer was evaluated based on the application of two liquid/liquid $(L / L)$ extraction methods. The gas chromatographic/mass spectrometric (GC/MS) method was used for the qualitative detection of the organic compounds present in the offset effluent. The cumulative qualitative GC/MS profile of organic substances in the waste offset developer indicates that the effluent contains 69 organic compounds with a probability of presence higher than $70 \%$ according to the AMDIS software and the NIST database.
\end{abstract}

Key words: offset developer, effluent, extraction, organic compounds

\section{INTRODUCTION}

An offset developer and a printing plate are in a close interdependent relationship. On one hand, the composition of the offset developer and the parameters according to which the developer is applied, like temperature, time of exposure, $\mathrm{pH}$ value, and age, affect the characteristics of the printing plate. On the other hand, the developer has to be adjusted in its composition to the type of the copy layer of the printing plate, the developing of which it is being used for (Mahovic Poljacek et al, 2012). Unfortunately, most manufacturers in Material Safety Data Sheet (MSDS) do not define the exact chemical composition of the offset developer or other offset printing liquid materials such as fountain solutions, cleaning agents, etc. Information about the chemical composition of offset printing materials are available partially in MSDS, in patent holders, or in scientific publications (Adamović, 2016; Adamović et al, 2019).

In literature data, a small number of authors have dealt with the problem of analysis of the initial and waste offset developers as well as their possible treatments. Thus, Vengris et al. (2007) state that in the starting developers under the commercial names of Polychrome 4003, Polychrome $2000 \mathrm{~K}$ and HD-P1 are the following chemical substances: potassium silicate, sodium silicate, potassium hydroxide, and Dsorbitol. After the process of developing, these waste offset developers are enriched by matters from the surface of the printing plate, such as: novolac, organic polymeric binders, photosensitive compounds, and pigments. Via the treatment by the Fenton's advanced oxidation process, almost all organic substances are removed (Vengris et al, 2007). In the paper by Lin et al. (2002), it is stated that the average waste offset developer consists of: p-phenylenediamine, hydroquinone, phenidone, benzyl alcohol, diethylene glycol, triethylene glycol, hydroxylamine, triethanolamine, formalin (consisting of $40 \%$ formaldehyde, $8 \%$ methanol and 52\% water), dialdehyde glutamic acid, organic heterocyclic compounds, p-toluene sulfonate, 5-sulfosalicylic acid, acetic acid, surfactants, then inorganic compounds (sodium sulfite, potassium sulfite, potassium carbonate, sodium hydrogen carbonate, boric acid, potassium hydroxide, sodium hydroxide, ammonium bromide and potassium bromide).

The waste offset developer as a byproduct of the developing of the offset printing plate is most commonly toxic by its characteristics and potentially harmful to the environment. For this purpose, this paper deals with the qualitative characterization of the organic load profile of the waste offset developer and with the validation of the two L/L extraction methods for the future selection of an adequate effluent treatment for its safe disposal in a printing environment.

\section{METHODS}

GC/MS method was used for the qualitative detection of the organic compounds present in the waste offset printing developer. A gas chromatograph with a mass detector (Agilent 7890A GC with 5975C MSD, USA) and with an Agilent J\&W Scientific DB-5MS chromatographic column of appropriate dimensions (30 $\mathrm{m} \times 0.25 \mathrm{~mm}$ ID $\times 0.25 \mu \mathrm{m}$ ) was used. The mass detector temperature was $150^{\circ} \mathrm{C}$, while the samples were 
injected at an injector with the temperature of $270^{\circ} \mathrm{C}$. Helium was used as the carrier gas (Adamović, 2016; Adamović et al, 2019).

Two $L / L$ extraction methods were used for the preparation of the waste offset printing developer samples: L/L extraction with methylene chloride (I method) and sequential L/L extraction with $n$-pentane, methylene chloride and methylene chloride at $\mathrm{pH} 2$ (II method).

In the I method, the extraction was performed in the following order: $1 \mathrm{~L}$ of waste printing developer was extracted with $30 \mathrm{ml}$ of methylene chloride $\left(\mathrm{CH}_{2} \mathrm{Cl}_{2}\right.$, J.T. Baker, USA) in a separation funnel. The extract was first collected in a laboratory beaker with three tablespoons of anhydrous sodium sulfate $\left(\mathrm{Na}_{2} \mathrm{SO}_{4}\right.$, p.a., Sigma-Aldrich, Germany) due to high contamination of the offset effluent. The extract was then transferred to a separation funnel. The extraction was repeated once more with another $30 \mathrm{ml}$ of methylene chloride. The cumulative extract was evaporated to dryness and reconstituted with $2 \mathrm{ml}$ of phenanthrene $\mathrm{d} 10(0.4 \mathrm{\mu g} / \mathrm{mL})$ in a mixture of hexane and methylene chloride $(1: 1)$. After the $\mathrm{L} / \mathrm{L}$ extraction with methylene chloride at the actual $\mathrm{pH}$ of the waste printing developer $(\mathrm{pH} 12.0)$, the $\mathrm{pH}$ of effluent was adjusted to 2 additions of concentrated hydrochloric acid ( $\mathrm{HCl}, 35 \%$, p.a., Merck, Germany). As the $\mathrm{pH}$ values of the compounds change their shape, adjusting the $\mathrm{pH}$ of effluent to 2, the invisible ionized compounds at $\mathrm{pH} 12.0$ become visible at $\mathrm{pH}$ 2. The L/L extraction process with methylene chloride at $\mathrm{pH} 2$ was repeated according to the same procedure as described above (Adamović, 2016; Adamović et al, 2019).

In the II method, the extraction was performed according to the procedure: $1 \mathrm{~L}$ of offset effluent was filtered through a membrane filtration set with a cellulose nitrate membrane filter (Sartorius Stedim Biotech $\mathrm{GmbH}$, Germany) and a vacuum pump (MILIPORE, Germany) to remove suspended solids from the waste offset developer. Then, $2 \mathrm{~mL}$ of 2,4,5,6-tetrachloro-m-xylene $(1 \mu \mathrm{g} / \mathrm{mL})$ and $2 \mathrm{~mL}$ of decachlorobiphenyl $(1 \mu \mathrm{g} / \mathrm{mL}$ ) were added to the filtered effluent. By the extraction with $50 \mathrm{ml}$ of $\mathrm{n}$ pentane, the first $\mathrm{n}$-pentane fraction was obtained. The $\mathrm{n}$-pentane fraction was filtered through anhydrous sodium sulfate. Following the same procedure with methylene chloride $(50 \mathrm{~mL})$ and methylene chloride at $\mathrm{pH} 2(50 \mathrm{~mL})$, the second and third fractions were obtained, respectively. Then, $400 \mu \mathrm{L}$ surrogate standards (chrysene-d12 and acenaften-d10) were added to all three fractions. Then the $\mathrm{n}$-pentane and methylene chloride fractions were evaporated in a stream of nitrogen to $1 \mathrm{~mL}$. The third fraction with methylene chloride in an acidic medium was subjected to a methylation procedure.

Methylation was performed according to the procedure of Santos-Delgado et al. (2000) as follows: the evaporated extract was dissolved in $1 \mathrm{~mL}$ of methanol. $250 \mu \mathrm{L}$ of concentrated sulfuric acid $\left(\mathrm{H}_{2} \mathrm{SO}_{4}\right.$ p.a., Merck, Germany) was slowly added to the extract, after which the extract was left in the ultrasonic bath for 1 minute. The extract was then heated in a water bath for 12 minutes at $59^{\circ} \mathrm{C} .6 \mathrm{~mL}$ of $2 \%$ potassium chloride solution was added to the cooled extract. The esters were extracted with $1 \mathrm{~mL}$ of hexane, and then $0.5 \mathrm{~mL}$ of the extract was separated for GC/MS analysis. After the evaporation of the first and second extracts and methylation and evaporation of the third extract, $2 \mu \mathrm{L}$ of phenanthrene d-10 (100 $\mu \mathrm{g} / \mathrm{mL}$ ) was added to each extract $(0.5 \mathrm{~mL}$ ). The prepared samples were analyzed by GC/MS (Adamović, 2016; Adamović et al, 2019). 1 L of distilled water as a blank sample was prepared for each fraction according to the same procedure as for the waste offset developer. The dishes were washed with the mixture of acetone: hexane in a 1: 1 ratio before use.

The Deconvolution Reporting Software was used to create the qualitative GC/MS organic profile of the offset effluent. The Automated Mass Spectral Deconvolution and Identification System (AMDIS) software was used to identify organic substances. Also, all mass spectra obtained with the AMDIS software were compared with the NIST (National Institute of Standards and Technology) reference spectra of the database. The presence of an organic compound in a waste offset developer sample has been proved if the probability of presence (match), obtained by using AMDIS software and the NIST database, is higher than 70\% (Adamović, 2016).

\section{RESULTS AND DISCUSSION}

By using the L/L extraction with methylene chloride (I method) and the sequential extraction (II method), 45 and 24 organic substances were detected in the waste offset developer, respectively. In order to obtain a qualitative profile with the maximum number of detected organic substances, a cumulative GC/MS profile was determined for both extraction methods. The cumulative and qualitative GC/MS profiles of organic substances in the waste offset developer indicate that the effluent contains 69 organic substances with a probability of presence (match) higher than $70 \%$ by using the AMDIS software and the NIST database (Table 1). 
Table 1 (part 1): Cumulative and qualitative GC/MS profile of organic substances in the waste offset developer

\begin{tabular}{|c|c|c|c|c|c|}
\hline $\begin{array}{c}\text { Class of } \\
\text { organic } \\
\text { compounds }\end{array}$ & Organic compounds & $\begin{array}{c}\text { I } \\
\text { method }\end{array}$ & $\begin{array}{c}\text { II } \\
\text { method }\end{array}$ & $\begin{array}{l}\text { AMDIS } \\
\text { Match }\end{array}$ & $\begin{array}{l}\text { NIST } \\
\text { Match }\end{array}$ \\
\hline \multirow{3}{*}{ Hydrocarbons } & Pentadecane & & + & 79 & 84 \\
\hline & Undecane & & + & 85 & 86 \\
\hline & Tetradecane & & + & 71 & 78 \\
\hline \multirow{2}{*}{$\begin{array}{l}\text { Bicyclic } \\
\text { hydrocarbons }\end{array}$} & 5-Ethyl-bicyclo [2.2.1] hept-2-ene & + & & 76 & 81 \\
\hline & Indane & + & & 88 & 79 \\
\hline \multirow{6}{*}{$\begin{array}{l}\text { Polycyclic } \\
\text { Aromatic } \\
\text { Hydrocarbons } \\
\text { (PAH) }\end{array}$} & Biphenyl & & + & 71 & 79 \\
\hline & Naphthalene & + & & 97 & 93 \\
\hline & 1-Naphthalenol & + & & 98 & 92 \\
\hline & 2-Naphthalenol & & + & 91 & 86 \\
\hline & Fluoranthene & + & & 90 & 84 \\
\hline & Pyrene & + & & 85 & 84 \\
\hline \multirow{6}{*}{ Alcohols } & 2-ethyl-1-Hexanol & & + & 99 & 92 \\
\hline & 1-Undecanol & + & & 75 & 81 \\
\hline & 1-Dodecanol & + & & 96 & 92 \\
\hline & 1-Tetradecanol & + & & 78 & 88 \\
\hline & Phenylmethanol or Benzyl Alcohol & & + & 100 & 94 \\
\hline & $\alpha, \alpha 4$-trimethyl-3-cyclohexene-1-Methanol & + & & 92 & 84 \\
\hline \multirow{2}{*}{ Ethers } & 2-(2-butoxyethoxy)-Ethanol & + & & 84 & 89 \\
\hline & 2-phenoxy-Ethanol & + & & 89 & 79 \\
\hline \multirow{5}{*}{$\begin{array}{l}\text { Aldehydes } \\
\text { and } \\
\text { Ketones }\end{array}$} & Benzaldehyde & + & & 97 & 94 \\
\hline & 2-chloro-1-phenyl-ethanone & & + & 87 & 90 \\
\hline & 2,3-dihydro-1H-Inden-1-one & + & & 78 & 77 \\
\hline & 1,2,3,4-tetrahydronaphthalen-1-one & + & & 72 & 76 \\
\hline & Diphenylmethanone & + & & 78 & 82 \\
\hline \multirow{11}{*}{ Phenols } & Phenol & + & & 87 & 82 \\
\hline & 3-methyl-Phenol & + & & 99 & 98 \\
\hline & 4-methyl-Phenol & + & & 100 & 94 \\
\hline & 2-ethyl-Phenol & + & & 72 & 74 \\
\hline & 3,5-dimethyl-Phenol & & + & 77 & 79 \\
\hline & 4-(1-methylethyl)-Phenol & & + & 73 & 70 \\
\hline & m-tert-butyl-Phenol & + & & 73 & 70 \\
\hline & p-tert-butyl-Phenol & & + & 87 & 85 \\
\hline & 2,4-di-tert-butyl-Phenol & + & & 96 & 89 \\
\hline & o-phenyl-Phenol & & + & 96 & 89 \\
\hline & Bis-4,4'-(1-methylethylidene)-Phenol & + & & 90 & 83 \\
\hline \multirow{13}{*}{$\begin{array}{l}\text { Substituted } \\
\text { benzenes and } \\
\text { benzene } \\
\text { derivatives }\end{array}$} & Methylbenzene & & + & 73 & 83 \\
\hline & 1-methyl-3-(1-methylethyl)-Benzene & & + & 83 & 87 \\
\hline & 1-methyl-3-propyl-Benzene & + & & 77 & 77 \\
\hline & 1-methoxy-4-(2-propenyl)-Benzene & & + & 91 & 85 \\
\hline & 4-methyl-1,2-diamino-Benzene & & + & 79 & 76 \\
\hline & Vanillin & + & & 86 & 80 \\
\hline & Benzoic acid & + & & 86 & 76 \\
\hline & 2,5-dimethyl-Benzoic acid & + & & 77 & 81 \\
\hline & 3,5-dimethyl-Benzoic acid & + & & 93 & 88 \\
\hline & p-tert-butyl-Benzoic acid & + & & 86 & 74 \\
\hline & Benzoic acid methyl ester & & + & 100 & 96 \\
\hline & Benzoic acid 4-methyl methyl ester & & + & 95 & 94 \\
\hline & Benzonitrile & + & & 73 & 73 \\
\hline \multirow{7}{*}{$\begin{array}{l}\text { Organic acids, } \\
\text { Esters and } \\
\text { Salts of } \\
\text { organic acids }\end{array}$} & 3-Phenylpropanoic acid & + & & 90 & 86 \\
\hline & Pentanoic acid & + & & 74 & 76 \\
\hline & Heptanoic acid & + & & 88 & 88 \\
\hline & Octanoic acid & + & & 88 & 86 \\
\hline & Nonanoic acid & + & & 92 & 88 \\
\hline & Decanoic acid & + & & 93 & 89 \\
\hline & Dodecanoic acid & + & & 97 & 94 \\
\hline
\end{tabular}


Table 1 (part 2): Cumulative and qualitative GC/MS profile of organic substances in the waste offset developer

\begin{tabular}{|l|l|c|c|c|c|}
\hline & Tertradecanoic acid & + & & 78 & 88 \\
\hline \multirow{5}{*}{} & Hexadecanoic acid & + & & 92 & 88 \\
\cline { 2 - 5 } & Octanoic methyl ester & & + & 95 & 92 \\
\cline { 2 - 5 } & Decanoic acid methyl ester & & + & 92 & 92 \\
\cline { 2 - 5 } & Dodecanoic acid methyl ester & & + & 96 & 93 \\
\cline { 2 - 5 } & Tetradecanoic acid methyl ester & & + & 98 & 94 \\
\cline { 2 - 5 } & Hexadecanoic acid methyl ester & + & & 98 & 91 \\
\cline { 2 - 5 } & 1-naphthyl methylcarbamate & + & & 91 & 70 \\
\cline { 2 - 6 } & $1(3 \mathrm{H})-$ Isobenzofuranone (lactone) & + & & 99 & 96 \\
\cline { 2 - 6 } & Phthalic anhydride & & + & 93 & 88 \\
\hline \multirow{5}{*}{ Terpenes } & N-butyl-1-Butanamine & + & & 100 & 98 \\
\cline { 2 - 6 } & Aniline & + & & 96 & 91 \\
\cline { 2 - 6 } & Diphenylamine & Camphor & + & 75 & 75 \\
\hline
\end{tabular}

By comparing the GC/MS profiles obtained by the I and II methods, it was found that the L/L extraction with methylene chloride (with 45 organic compounds) detected $47 \%$ more organic substances compared to the sequential L/L extraction (with 24 organic compounds). Also, bicyclic hydrocarbons, ethers, organic acids, some salts of organic acids, and terpene (camphor) were detected only by the L/L extraction with methylene chloride, while hydrocarbons and esters of organic acids were detected only in sequential $\mathrm{L} / \mathrm{L}$ extraction. It is concluded that the nature of the solvent determines the number and class of extracted organic compounds.

\section{CONCLUSIONS}

In case of a complex effluent such as the waste offset developer, in order to obtain a profile with a higher number of detected organic substances it is best to determine the cumulative GC/MS profile of both L/L extraction methods. The obtained cumulative GC/MS profiles show that almost 2 times more of the organic substances are detected by the $\mathrm{L} / \mathrm{L}$ extraction with methylene chloride compared to the sequential $\mathrm{L} / \mathrm{L}$ extraction. Thus, the extraction solvent determines the class of organic compounds that will be extracted from the offset effluent.

\section{ACKNOWLEDGMENTS}

This research (paper) has been supported by the Ministry of Education, Science and Technological Development through the project no. 451-03-68/2020-14/200156: "Innovative scientific and artistic research from the FTS (activity) domain".

\section{REFERENCES}

[1] Adamović, S.: "Electrocoagulation and Adsorption Treatments of Effluents in Offset Printing Graphic Processes", PhD thesis, University of Novi Sad, Faculty of Technical Sciences, Novi Sad, 2016.

[2] Adamović, S., Rajs, V., Mihailović, A., Lakatoš, R., Adamović, D.: "Characterization of the organic load of the waste fountain solution", Proceedings of 25th International Symposium on Analytical and Environmental Problems (ISAEP 2019: Szeged, Hungary, 2019), pages 453-457.

[3] Lin, B.-L., Hosomi, M., Murakami, A.: "Effects of high salinity and constituent organic compounds on treatment of photo-processing waste by a sulfur-oxidizing bacteria/granular activated carbon sludge system", Water Research, 36 (4), 1076-1083, 2002. doi: 10.1016/s0043-1354(01)00280-9.

[4] Mahovic Poljacek, S., Risovic, D., Cigula, T., Gojo, M.: “Application of electrochemical impedance spectroscopy in characterization of structural changes of printing plates", Journal of Solid State Electrochemistry, 16 (3), 1077-1089, 2012. doi: 10.1007/s10008-011-1490-9.

[5] Santos-Delgado, M.J., Crespo-Corral, E., Polo-Díez, L.M.: "Determination of herbicides in soil samples by gas chromatography: optimization by the simplex method", Talanta, 53 (2), 367-377, 2000. doi: 10.1016/s0039-9140(00)00498-7. 
[6] Vengris, T., Binkienè, R., Butkienè, R., Dikčius, A., Karitanas, R., Manusadžianas, L.: "Treatment of waste offset-printing developer with Fenton's reagent", Chemija, 18 (2), 1-6, 2007.

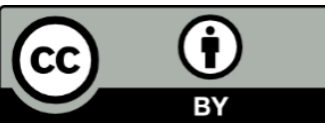

(C) 2020 Authors. Published by the University of Novi Sad, Faculty of Technical Sciences, Department of Graphic Engineering and Design. This article is an open access article distributed under the terms and conditions of the Creative Commons Attribution license 3.0 Serbia

(http://creativecommons.org/licenses/by/3.0/rs/). 